\title{
Does water level affect benthic macro-invertebrates of a marginal lake in a tropical river-reservoir transition zone?
}

\author{
Zerlin, RA. and Henry, R.* \\ Department of Zoology, Institute of Biosciences, State University of São Paulo - UNESP, \\ Campus of Botucatu, CP 510, CEP 18618-000, Botucatu, SP, Brazil \\ *e-mail: rhenry@ibb.unesp.br
}

Received December 12, 2012 - Accepted January 30, 2013 - Distributed May 31, 2014

(With 8 figures)

\begin{abstract}
Benthic macro-invertebrates are important components of freshwater ecosystems which are involved in ecological processes such as energy transfer between detritus and consumers and organic matter recycling. The aim of this work was to investigate the variation in organism richness, diversity and density of benthic fauna during the annual cycle in Camargo Lake, a lake marginal to Paranapanema River, southeast Brazil. The correlation of environmental factors with community attributes of the macro-benthic fauna was assessed. Since Camargo Lake is connected to the river, we tested the hypothesis that water level variation is the main regulating factor of environmental variables and of the composition and abundance of benthic macro-invertebrates. The results indicated that lake depth varied with rainfall, being the highest at the end of the rising water period and the lowest at the beginning of this period. The sediment granulometry was more heterogeneous at the bottom of the lake by the end of the high water period. The benthic macro-invertebrate fauna was composed by 15 taxa. The Diptera order was represented by seven taxa and had greater richness in relation to other taxa. This group was responsible for $60 \%$ of the total abundance of organisms, followed by Ephemeroptera (22\%) and Anellida (16\%). Significant differences were observed over time in total richness and, in density of Narapa bonettoi, Chaoborus, Ablabesmyia gr. annulata, Chironomus gigas, Larsia fittkau, and Procladius sp. 2. Total taxa richness correlated negatively with water $\mathrm{pH}$, transparency, conductivity, and bottom water oxygen. Higher positive correlations were found between the densities of some taxa and bottom water oxygen, conductivity and very fine sand, silt + clay of sediment, while negative correlations were recorded with organic matter, and fine, medium and coarse sand, bottom water temperature, mean temperature and rainfall. The significant temporal difference in water level was associated with changes in abiotic factors and macro-invertebrate community attributes.
\end{abstract}

Keywords: marginal lake, connectivity, water level, benthic fauna.

\section{O nível de água afeta os macro-invertebrados bentônicos de uma lagoa marginal na região de transição rio - represa de zona tropical?}

\begin{abstract}
Resumo
Os macro-invertebrados são componentes importantes de ecossistemas aquáticas continentais, envolvidos em processos ecológicos como transferência de energia entre detritos e consumidores e, reciclagem de matéria orgânica. O objetivo deste trabalho foi investigar a variação na riqueza de organismos, diversidade e densidade da fauna bentônica durante um ciclo anual na Lagoa do Camargo, marginal ao Rio Paranapanema, sudeste do Brasil. Eventuais relações de fatores ambientais com atributos da comunidade macro-bentônica foram verificadas. Visto que a Lagoa do Camargo é conectada com o rio, nós testamos a hipótese de que a variação do nível de água é o principal fator regulador das variáveis ambientais e da composição e abundância dos macro-invertebrados bênticos. Os resultados indicaram que a profundidade da lagoa variou com a precipitação, sendo mais alta no final do período da enchente e mais baixa no inicio deste período. A granulometria do sedimento foi mais heterogênea no fundo da lagoa no final do período de cheia. A fauna de macro-invertebrados bênticos foi composta de 15 taxa. A ordem Diptera foi representada por sete taxa e tem maior riqueza em relação aos outros taxa. Este grupo foi responsável por $60 \%$ da abundância total de organismos, seguido por Ephemeroptera (22\%) e Anellida (16\%). Diferenças temporais significativas foram observadas na riqueza total e, na densidade de Narapa bonettoi, Chaoborus, Ablabesmyia gr. annulata, Chironomus gigas, Larsia fittkau, and Procladius sp. 2. A riqueza total de taxa correlacionou-se negativamente com $\mathrm{pH}$ da água, transparência, condutividade e oxigênio na água do fundo. As mais altas correlações positivas foram encontradas entre as densidades de alguns taxa e oxigênio da água de fundo, condutividade e areia muito fina, silte + argila do sedimento, enquanto que correlações negativas foram obtidas com matéria orgânica, e areia fina, média e grossa, temperatura da água de fundo, temperatura média e precipitação. A diferença temporal significativa do nível de água foi associada a mudanças nos fatores abióticos e nos atributos da comunidade de macro-invertebrados.
\end{abstract}

Palavras-chave: lagoa marginal, conectividade, nível de água, fauna bêntica. 


\section{Introduction}

In flood areas marginal to lakes, water level variation is one of the main regulating factors of marginal environment communities. During the rising water period, the rivers invade marginal depressions, and when the water level decreases, lakes that are isolated or connected to the main channel are formed (Junk, 1980).

Different from that observed in floodplains, flood pulse frequency, duration and amplitude are modified at sites of confluence of lotic systems with artificial lacustrine ecosystems, such as reservoirs, where the action of hydrologic pulses of tributaries is greatly attenuated in the river-reservoir transition zone (Henry, 2005).

In the dry season, the influence of local agents (such as water input by underground flow) predominates and acts in distinct ways in each plain environment. During floods, the exchange of biological material, particulate and dissolved matter, nutrients, detritus, and biomass increases directly with the connectivity of the river to plain lacustrine environments (Thomaz et al., 2007).

Stream water velocity and depth of the marginal lakes adjacent to rivers and of the flooded area also are directly affected by the flood pulse (Thomaz et al., 2004). These are relevant factors that control the behavioural, morphological and anatomic patterns and physiological characteristics of organisms that live in these areas (Thomaz et al., 2004).

The temporal and spatial distribution of both benthic and planktonic populations is influenced by the water physical, chemical and biological factors. Among them, the nature of sediment, lake depth, water level fluctuation, dissolved oxygen, $\mathrm{pH}$, trophic status, and the competition of different populations are the main controlling factors of benthic fauna (Ward et al., 1995; Esteves, 1998; Galdean et al., 2000). The number of benthic taxa tends to be greater with the heterogeneity of the types of bottom substrata, since a heterogeneous environment affords a greater number of niches (Beisel et al., 2000).

Marginal lakes in river-reservoir transition environments have permanent connections with the tributaries. Due to the temporal variation of the hydrologic pulse, water quality and the nature of the sediment of marginal lakes may vary with lateral flooding from rivers. Since the temporal variation in abundance and richness of benthic communities under hydrologic changes is little known, the benthic fauna and associated abiotic parameters were surveyed for one year. The study hypothesis was that water level variation is the main regulating factor of environmental variables and the composition and abundance of benthic macro-invertebrates in marginal lakes.

\section{Material and Methods}

The Paranapanema River - Jurumirim Reservoir transition region is characterised by a great rate of deposition of allochthonous material that is carried by the river (Henry and Maricato, 1996) and by a decrease in stream velocity (Casanova and Henry, 2004). The coefficient of exportation of suspended solids of the basin, characterized as having forest cover $(24 \%)$, reforested areas $(20 \%)$ and pastures $(33 \%)$, was estimated at 13.7-15.5 t . $\mathrm{km}^{2}$. ton $^{-1}$ (Henry and Gouveia, 1993).

Camargo Lake, the lake selected for this study, is located at the mouth zone of Paranapanema River into Jurumirim Reservoir, São Paulo state (Figure 1). The lake is permanently connected to the river. Some studies of macro-invertebrates either associated with aquatic macrophytes (Afonso, 2002; Davanso, 2009; Fulan, 2006, 2009; Fulan and Henry, 2006, 2007, 2008; Fulan et al., 2009, 2011; Silva and Henry, 2013; Stripari and Henry, 2002) or with benthic habitats (Davanso, 2005, 2009; Davanso and Henry, 2006, 2007; Shimabukuro and Henry, 2011; Zerlin, 2011) have been conducted in this lake and in other nearby marginal lakes.

The efficiency of sediment deposition in Camargo Lake corresponds to $1 \%$ of the amount carried by the river (Henry, 2009). The presence of macrophyte stands along the entire river side, with the predominance of Echinochloa polystachya, is responsible for the retention of sediment in the river.

Three sites of Camargo Lake (2330'10'S/48 $\left.42^{\prime} 35^{\prime \prime} \mathrm{W}\right)$ were selected for study and sampled every month for one year. To better characterise the sampling sites, complementary physical-chemical data on the column of water and sediments were collected. Air temperature was measured with an alcohol thermometer; surface water temperature, with a Toho Dentam thermistor, and water transparency, with a Secchi disk. Oxygen dissolved in water was determined in surface and bottom water according to Golterman et al. (1978), water $\mathrm{pH}$ with $\mathrm{pHmeter}$ Micronal B-380, and water conductivity, corrected to $25^{\circ} \mathrm{C}$, with conductivimeter Hach Mod.2511. Rainfall data were obtained at Station E5-117 of the Department of Water and Electric Energy (Departamento de Águas e Energia Elétrica, DAEE), located at Angatuba, São Paulo state, at approximately $25 \mathrm{~km}$ from the study site.

Sediment was collected at each site using a Petersen dredge $\left(0.0640 \mathrm{~m}^{2}\right.$ area) for analysis of benthic fauna (three samples) and sediment characterization (one sample). Sediment composition was determined using the Wentworth scale (Suguio, 1973) and the organic matter content, by combustion in oven $\left(550{ }^{\circ} \mathrm{C} / 1 \mathrm{~h}\right)$.

The sediment sample was pre-screened in the field by washing with lake water through a $250-\mathrm{mm}$ mesh. The remaining material (sediment + fauna) was transferred to plastic pots, fixed with 4\% formal, and dyed with Phloxine B (Mason Junior and Yevich, 1967). In the laboratory, the biota was screened with a stereoscopic microscope and the organisms were identified using the Pennak (1978), Brinkhurst and Marchese (1991), Lopretto and Tell (1995), Merritt and Cummins (1996), Mugnai et al. (2010) and Trivinho-Strixino (2011) keys. Densities of individuals per $\mathrm{m}^{2}(\mathrm{~N})$ were determined using cumulative values of three samples. Relative density (\%) of each of the groups was obtained, and the taxa richness values (S) of each sampling site. The criteria used for the relative density indexes were according to McCullough and Jackson (1985). Groups with 


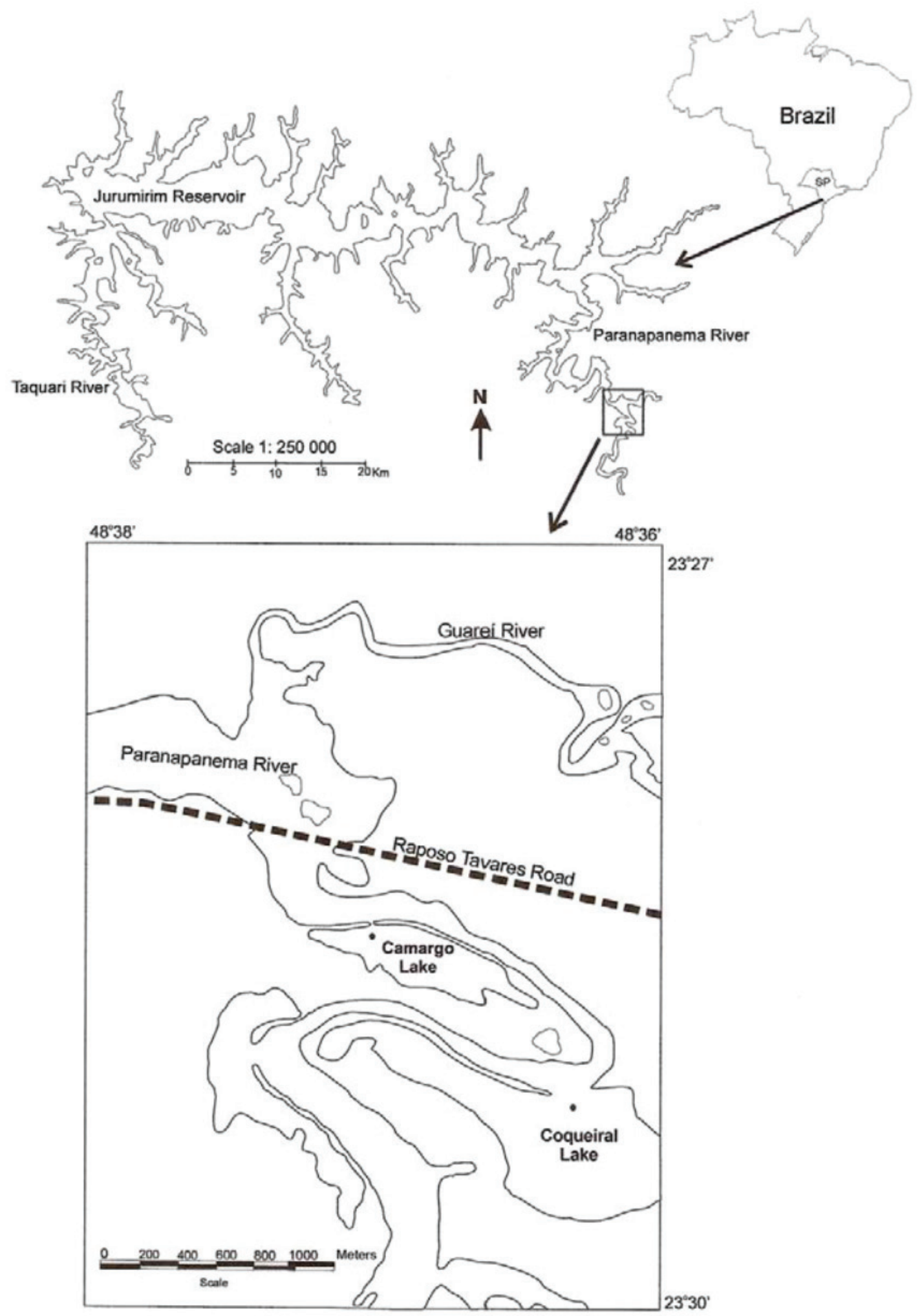

Figure 1. The study area: Jurumirim Reservoir, at the transition zone Paranapanema River/Jurumirim Reservoir, and the location of Camargo Lake (São Paulo, Brazil). 
density between 50 and 100\% were considered dominant, between 30 and 49\%, abundant, between 10 and 29\%, common, between 1 and 9\%, occasional, and less than $1 \%$, rare. Richness was expressed as the number of genera per sampling station.

Prior to statistical analysis, the data were log transformed $(\mathrm{X}+1)$. Significant variations $(\mathrm{P}<0.05)$ in environmental parameters and community ecological attributes of the macro-invertebrate community were determined by variance analysis (ANOVA) using the Statistic 6.0 (Statsoft, 2002) software after verification of requirements such as normality and variance homogeneity. Correlations between taxa richness and environmental variables were determined with Pearson's test, and between organism densities, by canonic correspondence analysis with 1,000 permutations using the "R" (R Development Core Team, 2009) software.

\section{Results}

Except for the water environmental variables, number of repetitions of which did not allow for the use of ANOVA analysis, all the other variables were significantly different on a monthly basis (Table 1). Significant temporal variations in sediment mean particle size from 7.39 (Aug. 2009) to 3.96 (Mar. 2010) were recorded (Table 2), being

Table 1. Differences determined by ANOVA ( $F$ and $p$ ) for environmental characteristics of sediment on the temporal scale.

\begin{tabular}{lcc}
\hline Environmental variables of sediment & F & P \\
\hline Depth & 4.50 & 0.00 \\
Organic matter & 4.50 & 0.00 \\
Very coarse sand & 11.86 & 0.00 \\
Coarse sand & 20.54 & 0.00 \\
Mean sand & 4.23 & 0.00 \\
Fine sand & 4.98 & 0.00 \\
Very fien sand & 14.01 & 0.00 \\
Silt + clay & 8.51 & 0.00 \\
\hline
\end{tabular}

more heterogeneous in September 2009 (Figure 2). The six granulometric classes (very coarse sand, coarse sand, medium sand, fine sand, very fine sand, silt and clay) were found in most months; however, silt + clay predominated, with values higher than $67 \%$ (Figure 2).

Differences in density and total taxa richness of benthic macro-invertebrates between months were found for Narapa, Chaoborus, Ablabesmyia gr. annulata, Chironomus gigas, Larsia fittkau, Procladius sp. 2, Campsurus (Table 3).

The total richness varied greatly during the study period, with the lowest value recorded in July 2010 and the highest value in September 2009 (Figure 3), when the water level, depth and organic matter content were the highest. The total density did not vary greatly from October to March and June to July. In these two periods, the density remained relatively low in comparison to the highest values, which were found in September, April and May (Figure 4).

The highest densities of Narapa bonettoi, Chironomus gigas, and Chaoborus were observed between August and

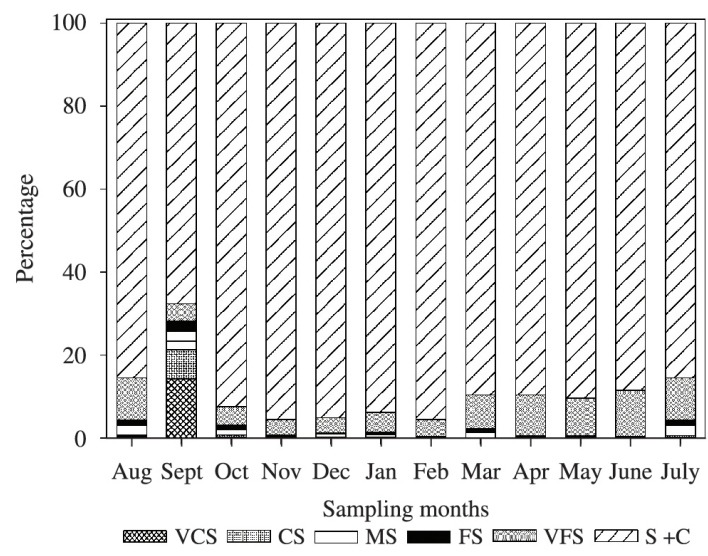

Figure 2. Granulometric composition of sediment at Camargo Lake, from August 2009 to July 2010 (For the abbreviations, see Table 4).

Table 2. Mean size of particle $\left({ }^{\phi}\right)$ on sediment of Lake Camargo during the study period.

\begin{tabular}{ccccccccccccc}
\hline Month Aug/09 & Sep & Oct & Nov & Dec & Jan/10 & Feb & Mar & Apr & May & Jun & Jul \\
\hline Size & 7.37 & 7.19 & 6.8 & 7.31 & 6.12 & 4.52 & 4.16 & 3.96 & 6.36 & 6.31 & 5.43 & 6.41 \\
\hline
\end{tabular}

Table 3. Differences determined by ANOVA (F and p) for total abundance and, of each taxa of benthic macro-invertebrates, as well as total richness on the temporal scale (in bold, significant values).

\begin{tabular}{lccclccc}
\hline & Abbreviations & $\mathbf{F}$ & $\mathbf{p}$ & & Abbreviations & F & $\mathbf{p}$ \\
\hline Total density & & 10.31 & $\mathbf{0 . 0 0}$ & Larsia fittkau & Larsi & 4.59 & $\mathbf{0 . 0 0}$ \\
Narapa bonettoi & Narap & 9.35 & $\mathbf{0 . 0 0}$ & Procladius sp2 & Procl & 3.94 & $\mathbf{0 . 0 0}$ \\
Branchiura sowerbyi & Branc & 1.23 & 0.32 & Pupa Diptera & PupaD & 0.73 & 0.70 \\
Corbicula fluminea & Corbi & 2.05 & 0.07 & Campsurus & Camps & 8.07 & $\mathbf{0 . 0 0}$ \\
Ceratopogonidae & Cerat & 0.91 & 0.55 & Batracobdella & Batra & 1.34 & 0.26 \\
Chaoborus & Chaob & 2.34 & $\mathbf{0 . 0 4}$ & Acari & Acari & 0.73 & 0.70 \\
Ablabesmyia gr. annulata & Ablab & 3.72 & $\mathbf{0 . 0 0}$ & Nematoda & Nemat & 0.91 & 0.55 \\
Chironomus & Chiro & 1.00 & 0.47 & Total richness & Tot Rich & 5.05 & $\mathbf{0 . 0 0}$ \\
Chironomus gigas & Chi gi & 3.10 & $\mathbf{0 . 0 1}$ & & & & \\
\hline
\end{tabular}


November 2009, together with the highest mean values of water level, rainfall, and organic matter (Figures 5, 6 and 7). In other months, the density of $N$. bonettoi decreased slightly, with the lowest values in June and July 2010. C. gigas presented a slight oscillation of density in the

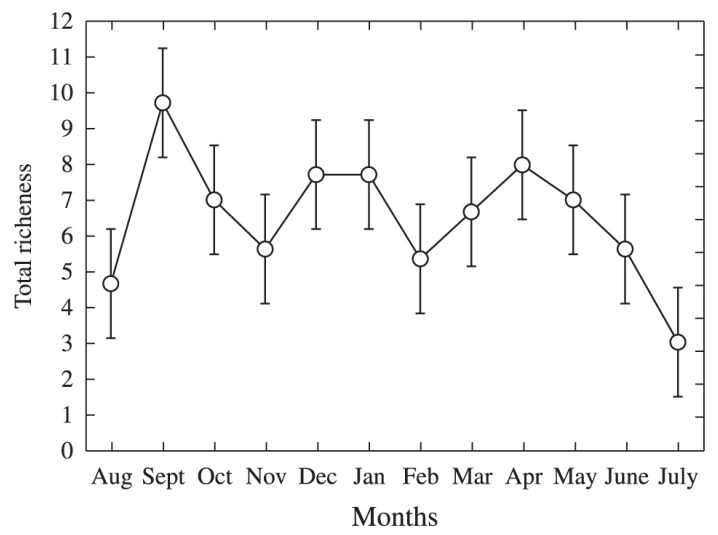

Figure 3. Variation of benthic total richness at Camargo Lake, from August 2009 to July 2010.

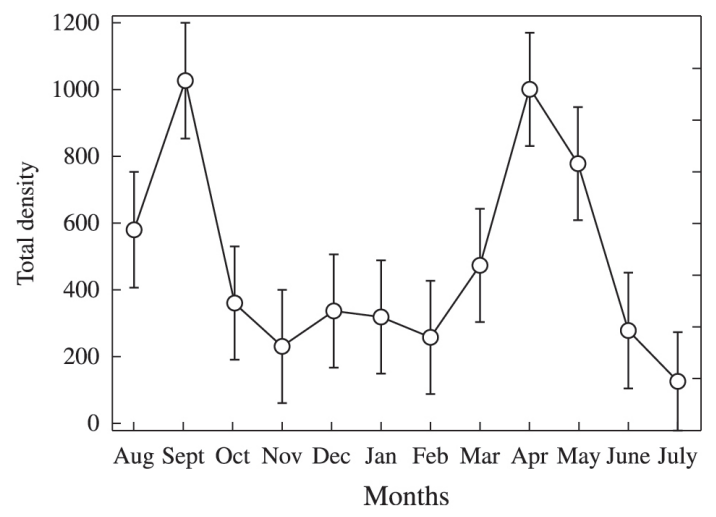

Figure 4. Variation of benthic fauna total density at Camargo Lake, from August 2009 to July 2010. other months. High density was found for Ablabesmyia gr. annulata only in May 2010, apparently without any correlation with environmental factors. In other months, large variations in density were observed. The highest density of Larsia fittkau was observed in March, April and May, which was associated with high water level, air temperature, lake surface and bottom water temperatures, and depth. Procladius sp. 2 and Campsurus presented higher density values in April and May, when the water level and depth were higher than in the other months.

Few Pearson's correlations between total richness and environmental variables were significant (Table 4). Taxa total richness correlated negatively with $\mathrm{pH}$, water transparency (Secchi) and conductivity, and dissolved oxygen in water at the bottom.

Table 5 presents the values of the canonic variables, canonic correlation coefficients, and significance test of macro-invertebrate richness. The canonic variables explained $69 \%$ of the data variance, considering two components ( $25 \%$ for $\mathrm{VC} 2$ and $44 \%$ for $\mathrm{VC} 1$ ) (Figure 8 ).

Temporal differences in the physical and chemical characteristics of sediment associated with some taxa and the type of sediment were observed (Figure 8).

Note that Campsurus correlated positively with axis 1 and was associated with oxygen dissolved in water at the bottom in April, June and July 2010, when the water level was low (Figure 8). Ablabesmyia gr. annulata and Procladius sp. 2 had the highest correlation with axis 1, positive with conductivity and very fine sand, in March and May 2010. Procladius sp. 2 had the strongest association in the month of May, when the water level was falling and conductivity was very high. Batracobdella and Larsia fittkau had the greatest correlation with axis 2, and positive correlation with sediment fraction silt + clay.

Analysis of the negative correlations with axis 1 showed that Chironomus gigas, Nematomorpha and Corbicula fluminea were strongly correlated with organic matter (OM). In axis 2, Ceratopogonidae correlated with the organic fraction of the sediment and fine, medium and coarse sand. Chaoborus correlated with coarse sand. All

Table 4. Pearson correlations between total richness of benthic taxa and environmental variables (in bold: significant correlations).

\begin{tabular}{|c|c|c|c|c|c|}
\hline $\begin{array}{c}\text { Environmental } \\
\text { variables }\end{array}$ & Abbreviations & Total richness & $\begin{array}{c}\text { Environmental } \\
\text { variables }\end{array}$ & Abbreviations & Total richness \\
\hline Air temperature & Air temp. & -0.04 & Depth & Depth. & 0.23 \\
\hline $\begin{array}{l}\text { Mean temperature of } \\
\text { water column }\end{array}$ & Mean temp. & 0.24 & Organic Matter & O.M. & 0.23 \\
\hline $\begin{array}{l}\text { Water temperature at } \\
\text { bottom }\end{array}$ & Bottom temp. & 0.31 & Very coarse sand & VCS & -0.02 \\
\hline $\mathrm{pH}$ & $\mathrm{pH}$ & -0.35 & Coarse sand & $\mathrm{CS}$ & 0.04 \\
\hline $\begin{array}{l}\text { Secchi disk } \\
\text { transparency }\end{array}$ & Secc. & -0.65 & Mean sand & MS & -0.05 \\
\hline Water conductivity & Cond. & -0.62 & Fine sand & FS & 0.05 \\
\hline OD at bottom & ODB & -0.42 & Very fine sand & VFS & -0.13 \\
\hline Rain Precipitation & Prec. & 0.31 & Silt + Clay & $\mathrm{S}+\mathrm{C}$ & -0.02 \\
\hline
\end{tabular}




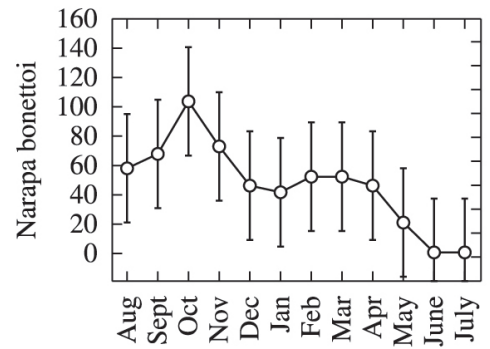

Months

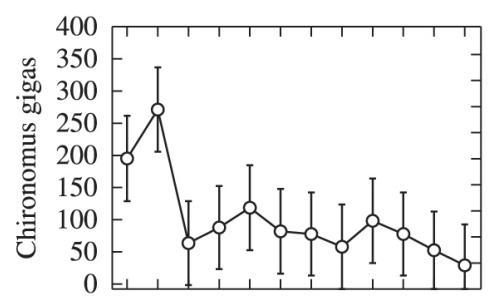

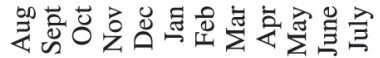

Months

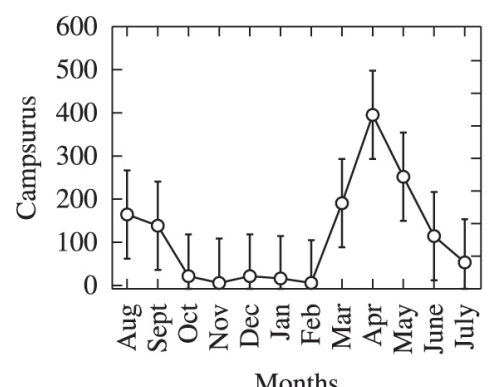

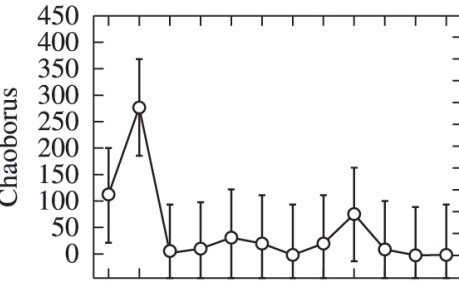

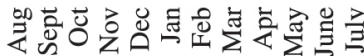

Months

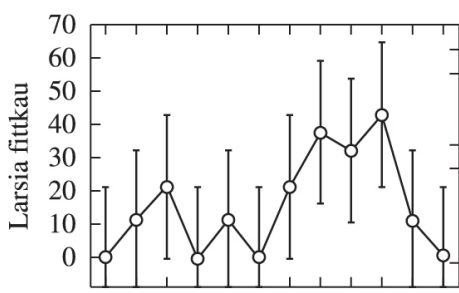

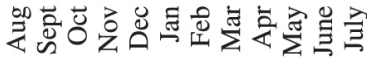

Months

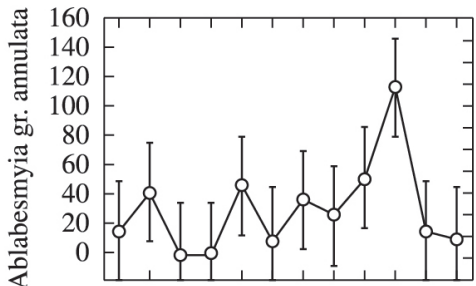

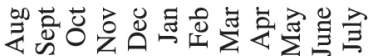

Months

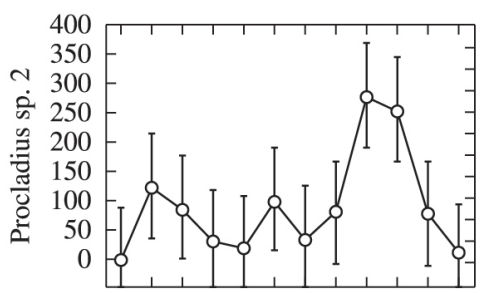

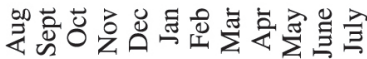

Months

Figure 5. Significant temporal variations of Narapa bonettoi, Chaoborus, Ablabesmyia gr. annulata, Chironomus gigas, Larsia fittkau, Procladius sp. 2 and Campsurus densities (ind.m ${ }^{-2}$ ) detected by ANOVA.

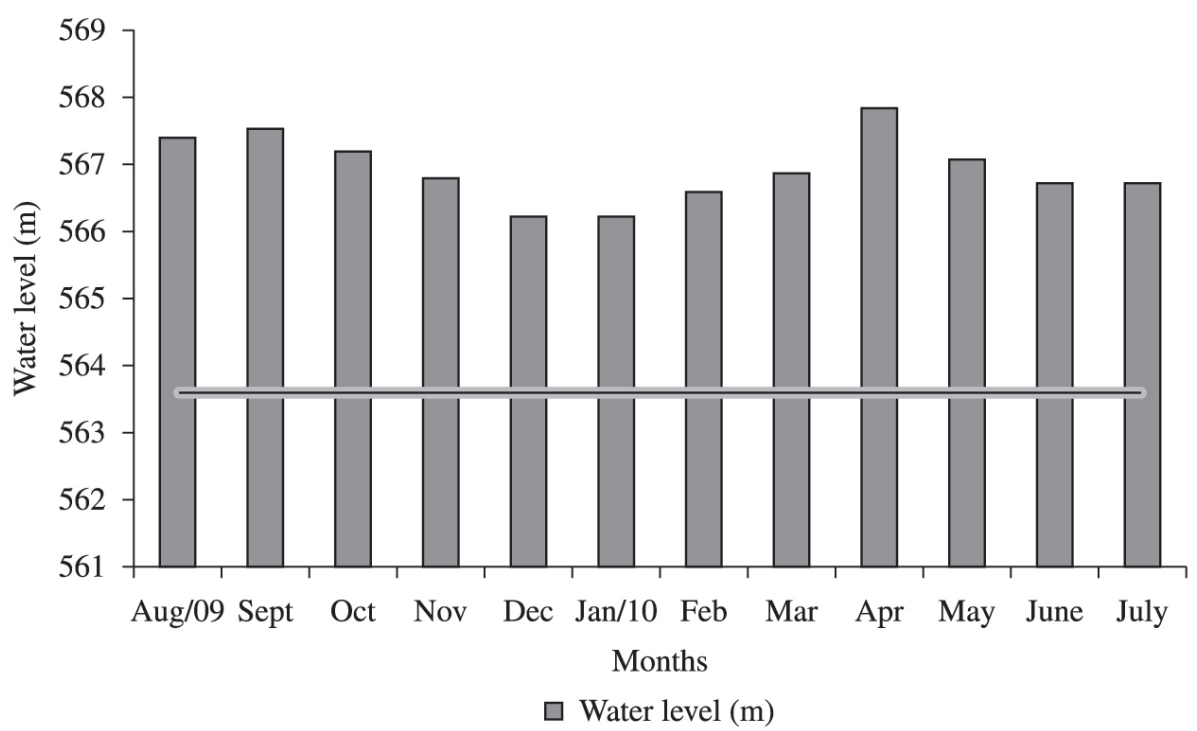

Figure 6. Water level (m) at Camargo Lake during the study period (The horizontal line at $563.60 \mathrm{~m}$ water level corresponds to the frontier of connection between lake and river). 


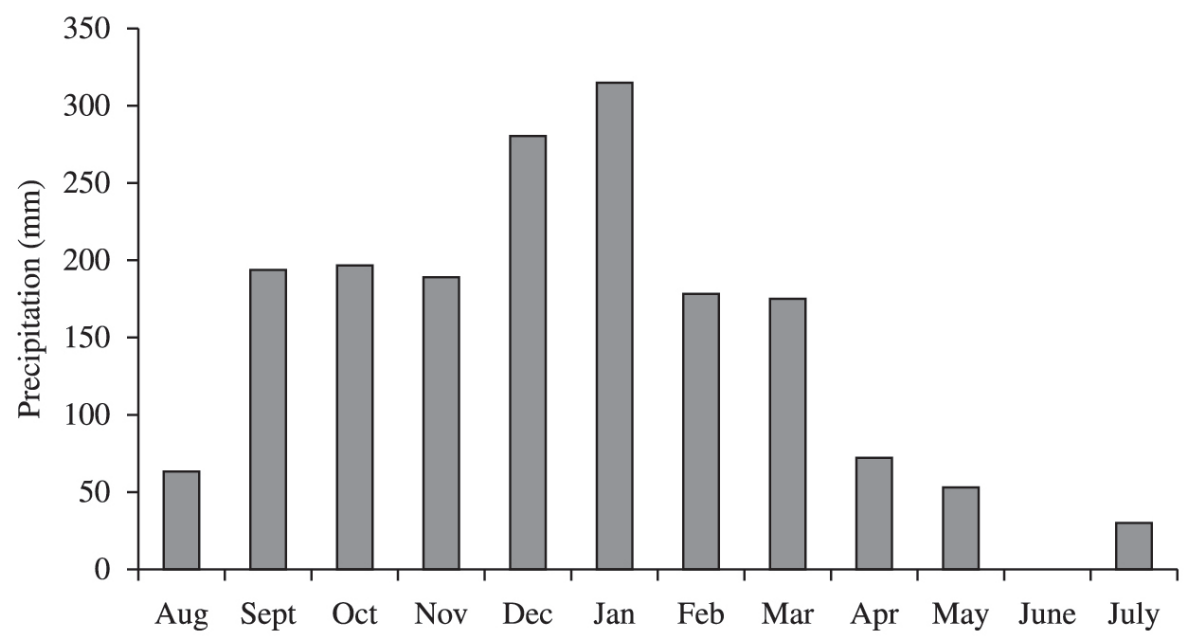

Figure 7. Monthly rain precipitation variation ( $\mathrm{mm}$ ) during the period study in the Angatuba region (São Paulo, Brazil).

Table 5. Scores of canonical variables (CA1 and CA2), adjusted canonical correlation coefficients $\left(\mathrm{r}^{2}\right)$ and, of significance levels (p) from the canonical correspondence analysis, between the abundances of benthic macro-invertebrates and environmental variables. (For abbreviations of taxa, see Table 3 and, of environmental variables, see Table 4) $\left({ }^{*} \mathrm{P}<0.05\right)$.

\begin{tabular}{cccccccccc}
\hline Variables & CA1 & CA2 & $\mathbf{r}^{\mathbf{2}}$ & $\mathbf{p}$ & Variables & $\mathbf{C A 1}$ & $\mathbf{C A 2}$ & $\mathbf{r}^{\mathbf{2}}$ & $\mathbf{p}$ \\
\hline Narap & -0.97 & 0.24 & 0.53 & $0.02 *$ & Depth & 0.99 & -0.03 & 0.19 & 0.44 \\
Branc & -0.98 & -0.17 & 0.38 & 0.11 & $\mathrm{pH}$ & 0.99 & 0.07 & 0.38 & 0.11 \\
Corbi & -0.75 & -0.65 & 0.25 & 0.22 & Mean Temp. & -0.70 & 0.70 & 0.47 & 0.07 \\
Cerat & -0.75 & -0.66 & 0.41 & 0.06 & Bottom Temp. & -0.64 & 0.76 & 0.53 & $0.03 *$ \\
Chaob & -0.57 & -0.81 & 0.71 & $0.00^{*}$ & Air Temp. & -0.92 & 0.37 & 0.14 & 0.53 \\
Ablab & 0.99 & -0.12 & 0.17 & 0.41 & Secc. & 0.98 & -0.15 & 0.26 & 0.23 \\
Chiro & -0.62 & -0.78 & 0.44 & $0.00^{*}$ & Cond. & 0.99 & 0.08 & 0.43 & 0.07 \\
Chi gig & -0.70 & -0.71 & 0.79 & $0.00^{*}$ & ODB & 0.93 & -0.34 & 0.58 & $0.03 *$ \\
Larsi & 0.88 & 0.45 & 0.38 & 0.12 & Prec. & -0.94 & 0.32 & 0.54 & $0.03 *$ \\
Procl & 0.98 & 0.14 & 0.26 & 0.23 & O.M. & -0.96 & -0.27 & 0.75 & $0.00^{*}$ \\
Pupa & -0.98 & 0.14 & 0.40 & 0.08 & VCS & -0.60 & -0.79 & 0.76 & $0.00 *$ \\
Camps & 0.84 & -0.53 & 0.51 & $0.03 *$ & CS & -0.60 & -0.79 & 0.79 & $0.00 *$ \\
Batra & 0.90 & 0.42 & 0.05 & 0.78 & MS & -0.55 & -0.83 & 0.68 & $0.00^{*}$ \\
Acari & 0.97 & -0.22 & 0.28 & 0.22 & FS & -0.58 & -0.81 & 0.54 & $0.03 *$ \\
Nemat & 0.77 & 0.63 & 0.23 & 0.35 & VFS & 0.99 & 0.05 & 0.91 & $0.00^{*}$ \\
& & & & & S+C & 0.39 & 0.91 & 0.79 & $0.00^{*}$ \\
\hline
\end{tabular}

taxa correlated with the months of August and September 2009, when the water level began to rise.

Lastly, the bottom temperature also had a strong negative correlation with axis 2 for Narapa bonettoi and Acari in November 2009 and February 2010, when the water level of Camargo Lake was nearly stable. The mean temperature of the column of water and rainfall had a strong correlation with Branchiura sowerbyi in December 2009 and January 2010, when lake depth was relatively low despite the high rainfall.

\section{Discussion}

According to Costa and Henry (2002), the intensity and frequency of the flood pulse in marginal lakes are related to the location of lakes on floodplains and their degree of connection with rivers. These factors also affect the limnological characteristics of these sites, since marginal lakes are very susceptible to flood and drought events.

The changes in the physical, chemical and biological factors observed in this study were related to the connection between Camargo Lake and Paranapanema River. The hydrological regime of the lake is also regulated by the operation of Jurumirim Reservoir and rainfall, which is marked by well-defined dry and rainy periods in this region (Moschini-Carlos et al., 1998).

From April to July 2010 rainfall was very low. Considering that this period is within the low water period, we observed that the total abundance of benthic organisms was higher than in the high rainfall period (December to January 2010), the end of the falling water 


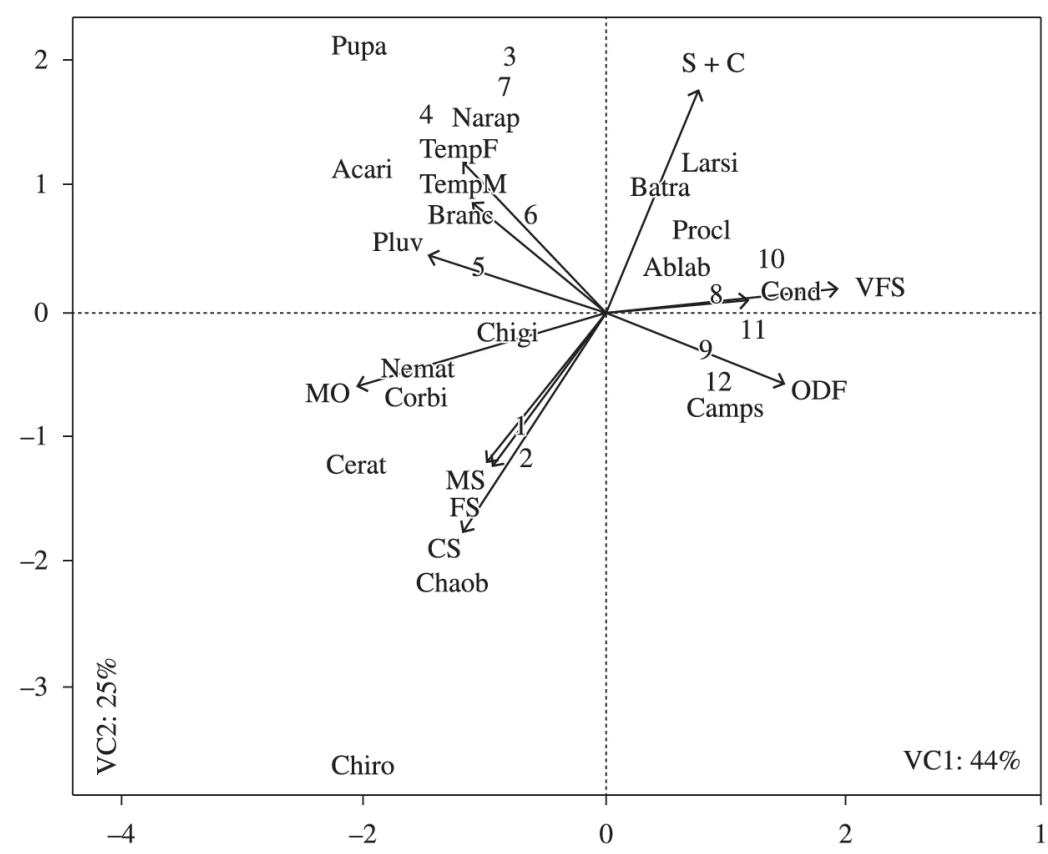

Figure 8. Biplot graphic from the canonical correspondence analysis between the environmental variables and the abundances of benthic macro-invertebrates. (For abbreviations of taxa, see Table 3 and Table 4; the numbers correspond to months: 1 (Aug), 2 (Sep), 3 (Oct), 4 (Nov), 5 (Dec), 6 (Jan), 7 (Feb), 8 (Mar), 9 (Apr), 10 (May), 11 (Jun), 12 (Jul).

and beginning of the rising water periods. In contrast, greater genus richness values were observed in the months with high rainfall. The increase in rainfall from December 2009 to January 2010, associated with high water and air temperatures, may have contributed to the eclosion of macro-invertebrates' eggs, and, therefore, to an increase in taxa richness (Panarelli et al., 2008).

Camargo Lake was continually connected to Paranapanema River during this study, as the water level was higher than the connection/disconnection threshold (563.60 m) with Paranapanema River (Henry, 2005).

In the months of greatest lake depth (September 2009 and April 2010), taxa density was the highest, with the predominance of Chaoborus and Procladius sp.2. When the lake was the shallowest (January 2010), at the end of the falling water and beginning of the rising water periods, the density of individuals was the lowest and the number of taxa, the highest.

In some months, positive correlation between water depth and transparency was recorded at Camargo Lake. Similar results were observed by Moschini-Carlos et al. (1998), Costa and Henry, (2002), Henry et al. (2005) and Mortari (2009). This variation during the year may be related to various factors, such as daily exchange of allochthonous matter in the river, sediment re-suspension during the drought period, outflow of allochthonous material from the lake bank in the rainy period (Henry, 2009; Moschini-Carlos et al., 1998). However, Camargo Lake presented a small variation in transparency during the study. The highest water transparency values were observed in the months of low water (August 2009 and
May, June and July 2010). In contrast, in the months when the river covered the lake completely, transparency was lower (September 2009 and January and February 2010) during the periods of rising and high water. Water level correlated significantly and negatively with total taxa richness, which was attributed to the lower transparency. However, organisms inhabit these sites, which present a high level of sediment organic matter.

Relative to the water temperature at the bottom of the lake, the lowest values were recorded in the low water period. From the middle of the falling water up to the end of the rising water period, the water temperature was the highest. The surface and bottom water temperatures were the lowest in the same period, in contrast to that observed by Granado and Henry (2008), who reported lower temperatures during the falling water period.

The highest $\mathrm{pH}$ values at both depths were recorded in the low water periods, which may have been related to the low rainfall and the pronounced degradation of organic matter in the lake that resulted from the submersion of the vegetation and/or water exchange with Paranapanema River (Thomaz et al., 1992; Esteves, 1998; Costa and Henry, 2002). The interactions of organic matter in the soil and the geological profiles lead to the formation of free organic acids, which increase the acidity of the aqueous medium (Custodio and Llamas, 1976; Stevenson, 1982). Likewise, the lowest $\mathrm{pH}$ values found in the rising water period may have been associated with high rainfall and possibly its diluting effect. This variable correlated significantly and negatively with total taxa richness. 
Mortari (2009) and Fulan and Henry (2007) found low values of oxygen dissolved in water in April 2006 and February and March 2007, after an intense rising water period, in contrast to the values found in this study, which lowest values were found in October 2009, the month with the highest water level, rainfall and organic matter. The highest values found are similar to those reported by Granado and Henry (2008) for the low water period (June and July 2010), with low rainfall and organic matter values.

Low conductivity values were observed at the end of the falling water period, possibly related to an increase in rainfall and a greater water input, a decrease in the amount of ions and a dilution effect (Pompêo et al., 1997; Moschini-Carlos et al., 1999). High water conductivity values were recorded in the low water period, possibly related to pronounced degradation of organic matter in the lake due to submersion of vegetation and/or water exchange with Paranapanema River (Thomaz et al., 1992; Costa and Henry, 2002).

According to Amorim et al. (2009), aquatic environments are depositional ecosystems and sediment records the processes that occur in the drainage basin. In recent years, sediment analysis has become more and more important in the evaluation of the quality of aquatic ecosystems due to its historical significance for the drainage basin. The importance of the processes of reutilisation of autochthonous and allochthonous matter and exchange and/or interaction of different chemical species with the column of water and the resident biota is also acknowledged (Håkanson and Jansson, 1983; Mozeto and Zagatto, 2006).

According to Fidelis et al. (2008), the abundance and diversity of macro-invertebrates are strongly influenced by the type of substratum. The Camargo Lake sediment is formed predominantly by silt and clay ( $>67 \%$ of the total). Greater bottom substratum heterogeneity was recorded in September 2009, together with the highest values for organic matter, water level and rainfall. Likewise, Davanso (2005) found silt and clay contents above $70 \%$ in Coqueiral Lake, which is located in the same region. Santos and Henry (2001) proposed that the main environmental factors affecting the benthic community of Jurumirim Reservoir, São Paulo State, are depth and sediment composition.

Hynes (2001) pointed out the existence of many types of organic matter in lotic systems, from fine fragments to filamentous algae to roots to whole trees and animals. In our study, Camargo Lake presented predominantly organic sediments in almost every month of the high water, falling water, and rising water periods, when autochthonous material was probably introduced into the Lake from the River.

According to Suriani et al. (2007), Oligochaeta are the most common and abundant benthic macro-invertebrates, and some species are considered good bioindicators, especially in water bodies with organic pollution. Many species prefer eutrophic water, living in sediment with abundant organic matter. In this study, the highest density was found in the months with the highest percentages of organic matter in the sediment.
Procladius sp. 2, one of the dominant taxa of Diptera in Camargo Lake, was also found in reservoirs (Brandimarte et al., 1999) and swamps, given its feeding plasticity (Nessimian, 1995).

Chaoborus, also predominant in Camargo Lake, is represented by cosmopolitan and predator organisms that live in high-latitude temperate environments and in tropical ecosystems (Borkent, 1993; Halat and Lehman, 1996). They are voracious predators of other benthic invertebrates, especially zooplankton, and can be found in sediment during the day and in the column of water at night (Hare and Carter, 1986; Hare, 1995). The preference of these organisms for environments with low oxygen concentration and deeper zones of lakes and reservoirs is well documented (Larow, 1970; Strixino, 1973; Strixino and Strixino, 1980; Rahel and Nutzman, 1994; Rabette and Lair, 1998; Corbi and Trivinho-Strixino, 2002; Jager and Walz, 2002).

In the temporal scale, besides Chironomus gigas, Branchiura sowerbyi and Chironomus were also constant. Branchiura sowerbyi, which had high densities during the whole year, has been reported as an indicator of organic pollution. They predominate in environments under environmental stress (Pamplin et al., 2006; Pamplin and Rocha, 2007; Suriani et al., 2007). In this study, they were in greater numbers in the high water period, when the sediment had a large quantity of organic matter.

According to Takeda et al. (2003), nymphs of Campsurus burrow into fine sediment and predominate in the high water period, when the concentration of dissolved oxygen in lakes is lower. Davanso and Henry (2007) observed a higher density of Campsurus in Coqueiral Lake when it was disconnected from the river and lake depth was low. In the present study, the density of Campsurus larvae correlated positively with lake depth, which varied with the river water level. On the other hand, it correlated negatively with water temperature and rainfall, making evident that the increase in abundance is related to a reduction in the lake volume in the coldest season of the year.

The greatest occurrence of macro-invertebrates was recorded in September 2009, when the water level, depth, and organic matter content were high and the sediment had a more heterogeneous granulometric composition. According to Van Brink et al. (1994), flood may remove macro-invertebrates from flooded lakes and carry them to the main river channel. At the same time, other river species are introduced into the lake environments. This can explain the fact that in the months with high water, taxa richness was low, since some macro-invertebrates may have been removed. The connectivity of the different habitats, such as rivers and lakes, can alter the dispersion, movement, and migration of organisms and thus determine the exchange of nutrients and organic matter between habitats (Sheldon et al., 2002).

No evident pattern was observed in the present work in the temporal variation of benthic macro-invertebrates, which raises questions on the tendency of seasonal variation of these organisms. The richness of the macro-invertebrate 
taxa studied did not vary much, suggesting that greater sampling of the studied environment is required to determine such tendency.

\section{Conclusions}

The variation in the volume of Camargo Lake with the flooding of Paranapanema River into the lake resulted in alterations of limnological variables and, consequently, of species. A significant difference was also observed for organisms subject to the influence of water abiotic factors, such as water level and transparency, suspended matter, dissolved oxygen, $\mathrm{pH}$, electric conductivity and temperature.

Variations were also observed in abundance. The months with the highest rainfall had higher genus richness and diversity than the low rainfall period.

Acknowledgements - The first author is grateful to CAPES for a scholarship. FUNDIBIO supported this research financially; Hamilton Antonio Rodrigues helped in the field, and Dr. Gilmar Perbiche Neves, and Keline Juliani Fabretti made valuable suggestions during the research; Laerte José da Silva revised the English language.

\section{References}

AFONSO, AAO., 2002. Relações da fauna associada a Eichhornia azurea (Swartz) Kunth com as variáveis abióticas em lagoas laterais de diferentes graus de conexão ao rio Paranapanema (zona de desembocadura na represa de Jurumirim, SP. Botucatu: Universidade Estadual Paulista. 99 p. Tese de Doutorado em Ciências Biológicas (Área Zoologia).

AMORIM, MA., MOREIRA-TURCQ, PF., TURCQ, BJ. and CORDEIRO, RC., 2009. Origem e dinâmica da deposição dos sedimentos superficiais na Várzea do Lago Grande de Curuai, Pará - Brasil. Acta Amazonica, vol. 39, no. 1, p. 165-171. http:// dx.doi.org/10.1590/S0044-59672009000100016.

BEISEL, JN., USSEGLIO-POLATERA, P. and MORETEAU, JC., 2000. The spatial heterogeneity of a river bottom: a key factor determining macroinvertebrate communities. Hydrobiologia, vol. 422-423, p. 163-171. http://dx.doi.org/10.1023/A:1017094606335.

BORKENT, R., 1993. A world catalogue of fóssil and extant Corethrellidae na Chaoboridae (Diptera), with a listing of references to Keys, bionomic information and descriptions of each known life stage. Entomologica Scandinavica, vol. 24, no. 1, p. 1-24. http://dx.doi.org/10.1163/187631293X00019.

BRANDIMARTE, AL., ANAYA, AL. and SHIMIZU, GY., 1999. Comunidade de invertebrados bentônicos nas fases pré- e pósenchimento em reservatórios: um estudo no caso de reservatório de aproveitamento múltiplo do rio Mogi-Guaçu (SP). In HENRY, R. (Ed.). Ecologia de reservatórios: estrutura, função e aspectos sociais. Botucatu: FAPESP/FUNDIBIO. p. 374-408.

BRINKHURST, RO. and MARCHESE, MR., 1991. Guia para la identificación de oligoquetos acuáticos continentales de sur y centroamérica. San Tomé: Associación Ciencias Naturales del Litoral.

CASANOVA, SMC. and HENRY, R., 2004. Longitudinal distribution of Copepoda populations in the transition zone of Paranapanema river and Jurumirim Reservoir (São Paulo, Brazil) and interchange with two lateral lakes. Revista Brasileira de
Biologia = Brazilian Journal of Biology, vol. 64, no. 1, p. 11-26. http://dx.doi.org/10.1590/S1519-69842004000100003.

CORBI, JJ. and TRIVINHO-STRIXINO, S., 2002. Spatial and bathymetric distribution of the macrobenthic fauna of the Ribeirão das Anhumas reservoir (Américo Brasiliense-SP, Brasil). Acta Limnologica Brasiliensia, vol. 14, no. 1, p. 35-42.

COSTA, MLR. and HENRY, R., 2002. Biomassa e composição química de Eichhornia azurea de três lagoas laterais ao Rio Paranapanema na zona de sua desembocadura na Represa de Jurumirim (São Paulo). Hoehnea, vol. 29, no. 2, p. 65-77.

CUSTODIO, E. and LLAMAS, MR., 1976. Hidrologia subterrânea. Barcelona: Omega. vol. 2

DAVANSO, RCS. and HENRY, R., 2006. A biodiversidade bentônica em lagoa marginal ao rio Paranapanema na zona de sua desembocadura na Represa de Jurumirim. Acta Scientiarum. Biological Sciences, vol. 28, no. 4, p. 347-357.

DAVANSO, RCS. and HENRY, R., 2007. Composition and abundance of Chironomidae and Ephemeroptera in a lateral lake in the mouth zone of Paranapanema River into Jurumirim Reservoir (State of São Paulo). Acta Limnologica Brasiliensia, vol. 19, no. 2, p. 131-142.

DAVANSO, RCS., 2005. A restauração da biodiversidade bentônica após periodo prolongado de seca em lagoa marginal ao Rio Paranapanema na zona de sua desembocadura na represa de Jurumirium - São Paulo. Botucatu: Universidade Estadual Paulista. 70 p. Dissertação de Mestrado em Ciências Biológicas (Área Zoologia).

DAVANSO, RCS., 2009. Composição e abundância de larvas de Chironomidae (Insecta: Diptera) associadas ao sedimento e a macrófita aquática (Salvinia auriculata) em dois rios e duas lagoas marginais com e sem conexão com o curso de água. Botucatu: Universidade Estadual Paulista. 112 p. Tese de Doutorado em Ciências Biológicas (Área Zoologia).

ESTEVES, FA., 1998. Fundamentos de limnologia. 2nd ed. Rio de Janeiro: Interciência/FINEP.

FIDELIS, L., NESSIMIAN, JL. and HAMADA, N., 2008. Distribuição espacial de insetos aquáticos em igarapés de pequena ordem na Amazônia Central. Acta Amazonica, vol. 38, no. 1, p. 127-134. http://dx.doi.org/10.1590/S0044-59672008000100014.

FULAN, JA. and HENRY, R., 2008. Variação anual da biomassa de Telebasis (Odonata, Coenagrionidae), junto a Eichhornia azurea (Sw.) Kunth, na Lagoa do Camargo (lateral ao Rio Paranapanema - São Paulo). Estudos de Biologia, vol. 30, p. 117-123.

FULAN, JA., 2009. Metodologias de amostragem em macrófitas e seu efeito na abundância de Odonata. Estudos de Biologia, vol. 73-75, p. 67-73.

FULAN, JA. and HENRY, R., 2006. The Odonata assemblage on Eichhornia azurea stands in Camargo Lake, a lateral lake on the Paranapanema River (São Paulo), after an extreme inundation episode. Acta Limnologica Brasiliensia, vol. 18, no. 4, p. 423-431.

FULAN, JA. and HENRY, R., 2007. Distribuição temporal de imaturos de Odonata (Insecta) associado a Eichhornia azurea (Kunth) na Lagoa do Camargo, Rio Paranapanema, São Paulo. Revista Brasileira de Entomologia, vol. 51, no. 2, p. 224-227. http://dx.doi.org/10.1590/S0085-56262007000200013.

FULAN, JA., DAVANSO, RCS. and HENRY, R., 2011. A profundidade como fator determinante na variação anual da 
densidade dos macroinvertebrados associados à Salvinia auriculata Aublet. Revista Brasileira de Biociências, vol. 9, no. 2, p. 214-219.

FULAN, JA., FIGUEIREDO, D. and RAIMUNDO, R., 2009. Effect of construction of Reservoir of Alqueva (Portugal) in diversity of dragonflies. Limnetica, vol. 29, p. 279-286.

FULAN, JA.,2006. Colonização por larvas de Odonata em Eichhornia azurea (Kunth) na Lagoa do Camargo, lateral ao Rio Paranapanema (zona de desembocadura do Reservatório de Jurumirim, SP), após episódio de inundação extraordinária. Botucatu: Universidade Estadual Paulista. 93 p. Dissertação de Mestrado em Ciências Biológicas (Área Zoologia).

GALDEAN, N., CALLISTO, M. and BARBOSA, FAR., 2000. Lotic Ecosystems of Serra do Cipó, southeast Brazil: water quality and a tentative classification based on the benthic macro-invertebrate community. Aquatic Ecosystem Health \& Management, vol. 3, no. 4 , p. 545-552.

GOLTERMAN, HL., CLYMO, RS. and OHNSTAD, MAM., 1978. Methods for physical and chemical analysis of freshwater. Oxford: Blackwell Scientific Publications.

GRANADO, DC. and HENRY, R., 2008. The influence of the hydrologic pulse on the water physical and chemical variables of lateral lakes with different connection levels to Paranapanema Rivers in the mouth zone at Jurumirim Reservoir (São Paulo Brasil). Acta Limnologica Brasiliensia, vol. 20, no. 4, p. 265-275.

HÅKANSON, L. and JANSSON, M., 1983. Principles of lakes sedimentology. Berlin: Springer-Verlag. 316 p.

HALAT, KM. and LEHMAN, JT., 1996. Temperature-dependent energetics of Chaoborus populations: hypothesis for anomalous distributions in the great lakes of East Africa. Hydrobiologia, vol. 330, no. 1, p. 31-36. http://dx.doi.org/10.1007/BF00020820.

HENRY, R. and GOUVEIA, L., 1993. Os fluxos de nutrientes e seston em cursos de água do Alto Paranapanema (São Paulo) - sua relação com usos do solo e morfologia das bacias de drenagem. Anais da Academia Brasileira de Ciencias, vol. 65, no. 4 , p. 439-451.

HENRY, R. and MARICATO, FE., 1996. Sedimentation rates of tripton in Jurumirim Reservoir (São Paulo, Brazil). Limnologica, vol. 26 , no. 1 , p. $15-25$.

HENRY, R., 2005. The connectivity of the Paranapanema river with two lateral lakes in its mouth zone into the Jurumirim reservoir. Acta Limnologica Brasiliensia, vol. 17, no. 1, p. 57-69.

HENRY, R., 2009. Annual changes in sediment entrapement efficiency in lakes lateral to a river (Paranapanema River, São Paulo, Brazil). Acta Limnologica Brasiliensia, vol. 21, no. 1, p. 25-34.

HENRY, R., PANARELLI, EA., CASANOVA, SMC., SUIBERTO, MR. and AFONSO, AAO., 2005. Interações hidrológicas entre lagoas marginais e o Rio Paranapanema na zona de desembocadura na Represa de Jurumirim. In NOGUEIRA, MG., HENRY, R. and JORCIN, A. (Ed.). Ecologia de reservatórios: impactos potenciais, ações de manejo e sistemas em cascata. São Carlos: Rima. p. 57-82.

HYNES, HBN., 2001. The ecology of running waters. 1st ed. Ontario: The Blackburn Press.

JAGER, IS. and WALZ, N., 2002. Chaoborus flavicans (Diptera) is an oxyregulator. Archiv fuer Hydrobiologie, vol. 155, p. 401-411.

JUNK, WJ., 1980. Áreas inundáveis: um desafio para a Limnologia. Acta Amazonica, vol. 10, no. 4, p. 775-795.
LAROW, EJ., 1970. The effect of oxygen tension of the vertical migration of Chaoborus larvae. Limnology and Oceanography, vol. 15, no. 3, p. 357-362. http://dx.doi.org/10.4319/lo.1970.15.3.0357.

LOPRETTO, EC. and TELL, G.,1995. Ecossistemas de aguas continentales: metodologias para su studio. Buenos Aires: Ediciones Sur. Tomo 3.

MASON JUNIOR, WT. and YEVICH, PP., 1967. The use of Phloxine B and Rose Bengal stains to facilitate sorting benthic samples. Transactions of the American Microscopical Society, vol. 86, no. 2, p. 221-223. http://dx.doi.org/10.2307/3224697.

MCCULLOUGH, JD. and JACKSON, DW., 1985. Composition and productivity of the benthic macroinvertebrate community of a subtropical reservoir. Internationale Revue der Gesamten Hydrobiologie, vol. 70, no. 2, p. 221-235. http://dx.doi.org/10.1002/ iroh. 19850700206.

MERRITT, RW. and CUMMNINS, KW., 1996. An introduction to the aquatic insects of North America. 3rd ed. Dubuque: Kendall/Hunt.

MORTARI, RC., 2009. Distribuição espaço-temporal de Cladocera (Crustacea, Branchiopoda) em uma lagoa subtropical lateral ao Rio Paranapanema (zona de desembocadura na Represa de Jurumirim/SP). Botucatu: Universidade Estadual Paulista. 172 p. Tese de Doutorado em Ciências Biológicas (Área Zoologia).

MOSCHINI-CARLOS, V., POMPÊO, MLM. and HENRY, R., 1998. Caracterização limnológica de uma baía marginal ao rio Paranapanema (zona de desembocadura na represa de Jurumirim, SP). Acta Limnologica Brasiliensia, vol. 10, no. 2, p. 1-19.

MOSCHINI-CARLOS, V., POMPÊO, MLM. and HENRY, R., 1999. Dinâmica da comunidade perifítica na zona de desembocadura do Rio Paranapanema, Represa de Jurumirim, SP. In HENRY, R. (Ed.). Ecologia de reservatórios: estrutura, função e aspectos sociais. Botucatu: FAPESP/FUNDIBIO. p.713-734

MOZETO, AA. and ZAGATTO, PA.,2006. Introdução de agentes químicos no ambiente. In ZAGATTO, PA. and BERTOLETTI, E. (Ed.). Ecotoxicologia aquática: princípios e aplicações. 1st ed. São Carlos: Rima. p.15-38.

MUGNAI, R., NESSIMIAN, JL. and BAPTISTA, DF., 2010. Manual de identificação de macroinvertebrados aquáticos do estado do Rio de Janeiro. 1st ed. Rio de Janeiro: Technical Book.

NESSIMIAN, JL., 1995. Abundância da fauna de macroinvertebrados de um brejo entre dunas no litoral do Estado do Rio de Janeiro. Revista Brasileira de Biologia = Brazilian Journal of Biology, vol. 55, p. 661-683.

PAMPLIN, PAZ. and ROCHA, O., 2007. Temporal and bathymetric distribution of benthic macro-invertebrates in the Ponte Nova reservoir, Tietê river (Sao Paulo, Brazil). Acta Limnologica Brasiliensia, vol. 19, no. 40, p. 439-452.

PAMPLIN, PAZ., ALMEIDA, TCM. and ROCHA, O., 2006. Composition and distribution of benthic macroinvertebrates in Americana Reservoir (SP, Brazil). Acta Limnologica Brasiliensia, vol. 18 , no. 2, p. 121-132.

PANARELLI, EA., CASANOVA, SMC. and HENRY, R., 2008. The role of resting eggs in the recovery of zooplankton community in a marginal lake of the Paranapanema River (São Paulo, Brazil), after a long drought period. Acta Limnologica Brasiliensia, vol. 20 , no. 1 , p. $73-88$.

PENNAK, RW., 1978. Freshwater invertebrates of the United States. New York. 2nd ed. New York: John Wiley \& Sons. 
POMPÊO, MLM., HENRY, R., MOSCHINI-CARLOS, V. and PADOVANI, CR., 1997. O papel da macrófita aquática Echinochloa polystachya (H.B.K.) Hitchcock na caracterização física e química da água na zona de desembocadura do Rio Paranapanema na Represa de Jurumirim. Brazilian Journal of Ecology, vol. 1, no. 2, p. 44-53.

R Development Core Team, 2009. A language and environment for statistical computing. Vienna: R Foundation for Statistical Computing. Available from: $<$ http://www.R-project.org $>$. Access in: 15 Apr. 2009

RABETTE, C. and LAIR, N., 1998. Influence des facteurs abiotiques sur la sortie des sédiments de Cyclops vicinus et Chaoborus flavicans dans les zones sub-littorale et profonde d'un lac tempéré eutrophe. Annales de Limnologie, vol. 34, no. 3, p. 295-303. http://dx.doi.org/10.1051/limn/1998026.

RAHEL, FJ. and NUTZMAN, JW., 1994. Foraging in a lethal environment: fish predation in hypoxic waters of a stratified lake. Ecology, vol. 75, no. 5, p. 1246-1253. http://dx.doi. org/10.2307/1937450.

SANTOS, CM. and HENRY, R., 2001. Composição, distribuição e abundância de Chironomidae (Diptera, Insecta) na represa de Jurumirim (Rio Paranapanema, SP). Acta Limnologica Brasiliensia, vol. 13, no. 2, p. 99-115.

SHELDON, F., BOULTON, AJ. and PUCKRIDGE, JT., 2002. Conservation value of variable connectivity: aquatic invertebrate assemblages of channel and floodplain habitats of a central Australian arid-zone river, Cooper Creek. Biological Conservation, vol. 103, no. 1, p. 13-31. http://dx.doi.org/10.1016/S0006-3207(01)00111-2.

SHIMABUKURO, EM. and HENRY, R., 2011. Controlling factors and benthic macroinvertebrate distribution in a small tropical pond, lateral to the Paranapanema River (São Paulo, Brazil). Acta Limnologica Brasiliensia, vol. 23, no. 2, p. 154-163. http:// dx.doi.org/10.1590/S2179-975X2011000200006.

SILVA, CV. and HENRY, R., 2013. Aquatic macroinvertebrates associated with Eichhornia azurea (Swartz) Kunth and relationships with abiotic factors in marginal lentic ecosystems (São Paulo, Brazil). Revista Brasileira de Biologia = Brazilian Journal of Biology, vol. 73, no. 1, p. 149-162. http://dx.doi.org/10.1590/ S1519-69842013000100016.

Statsoft, 2002. Statistica (data analysis software system). version 6. Tulsa: Statsoft Inc. Available from: <www.statsoft.com>.

STEVENSON, FJ., 1982. Humus chemistry: genesis, composition, reactions. New York: John Wiley and Sons.

STRIPARI, NL. and HENRY, R., 2002. The invertebrate colonization during decomposition of Eichhornia azurea kunth in a lateral lake in the mouth zone of Paranapanema River into Jurumirim Reservoir (São Paulo, Brazil). Revista Brasileira de Biologia = Brazilian Journal of Biology, vol. 62, no. 2, p. 293-310. http:// dx.doi.org/10.1590/S1519-69842002000200014.
STRIXINO, GBMA. and STRIXINO, ST., 1980. Macro-invertebrados do fundo da represa do Lobo (Estado de São Paulo - Brasil) e Distribuição e abundância de Chironomidae e Chaoboridae (Diptera). Tropical Ecology, vol. 21, no. 1, p. 16-23.

STRIXINO, GBMA., 1973. Sobre a ecologia dos macro-invertebrados do fundo, na represa do Lobo. São Paulo: Universidade de São Paulo. 188 p. Tese de Doutorado em Zoologia.

SUGUIO, K., 1973. Introdução a sedimentologia. São Paulo: Edgard Blücher.

SURIANI, AL., FRANÇA, RS., PAMPLIM, PAZ., MARCHESE, M., LUCCA, JV. and ROCHA, O., 2007. Species richness and distribution of oligochaetes in six reservoirs on Middle and Low Tietê river (SP, Brazil). Acta Limnologica Brasiliensia, vol. 19, no. 4, p. 415-426.

TAKEDA, AM., SOUZA-FRANCO, GM., MELO, SM. and MONKOLSKI, A., 2003. Invertebrados associados às macrófitas aquáticas da planície de inundação do alto rio Paraná (Brasil). In THOMAZ, SM. and BINI, LM. (Ed.). Ecologia e manejo de macrófitas aquáticas. Maringá: EDUEM. p. 243-260.

THOMAZ, SM., BINI, LM. and BOZELLI, RL., 2007. Floods increase similarity among aquatic habitats in river-floodplain systems. Hydrobiologia, vol. 579, no. 1, p. 1-13. http://dx.doi. org/10.1007/s10750-006-0285-y.

THOMAZ, SM., LANSAC-TÔHA, FA., TOBERTO, MC., ESTEVES, FA. and LIMA, AF., 1992. Seasonal variation of some limnological factors of lagoa do Guaraná, a várzea lake of the high rio Paraná, state of Mate Grosso do Sul, Brazil. Revue d'Hydrobiologie Tropicale, vol. 25, no. 4, p. 269-276.

THOMAZ, SM., PAGIORO, TA., BINI, LM., ROBERTO, MC. and ROCHA, RRA., 2004. Limnological characterization of the aquatic environments and the influence of hydrometric levels. In THOMAZ, SM., AGOSTINHO, AA. and HAHN, NS. (Ed.). The upper Paraná River and its floodplain: physical aspects, ecology and conservation. Leiden: Backhuys Publishers. p. 75-102

TRIVINHO-STRIXINO, S., 2011. Larvas de Chironomidae: guia de identificação. São Carlos: EdUFSCar. p. 1-371.

VAN BRINK, FWBD., BELJAARDS, MJ., BOOTS, NCA. and VAN VELDE, GD., 1994. Macro-zoobenthos abundance and community composition in three lower Rhine floodplain lakes with varying inundation regimes. Regulated Rivers: Research and Management, vol. 9, no. 4, p. 279-293. http://dx.doi.org/10.1002/ rrr.3450090408.

WARD, D., HOLMES, N. and JOSÉ, P., 1995. The new rivers \& wildlife handbook. Bedfordshire: Royal Society for the Protection of Birds.

ZERLIN, RA., 2011. Variação temporal dos macroinvertebrados bentônicos em lagoa marginal ao Rio Paranapanema. Botucatu: Universidade Estadual Paulista. 96 p. Dissertação de Mestrado em Ciências Biológicas (Área Zoologia). 